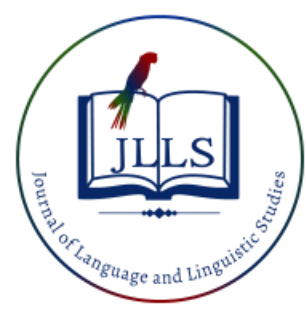

Available online at www.jlls.org

JOURNAL OF LANGUAGE AND LINGUISTIC STUDIES

ISSN: 1305-578X

Journal of Language and Linguistic Studies, 17(1), 70-84; 2021

\title{
Aliya madrasah students' motivation for learning English in Bangladesh
}

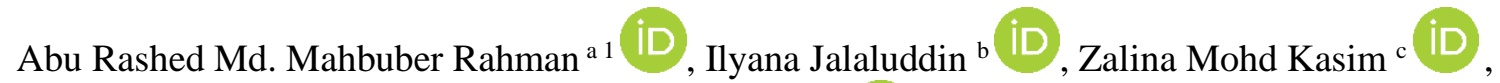 \\ Ramiza Darmi diD \\ a,b,c,d Universiti Putra Malaysia, Malaysia
}

\section{APA Citation:}

Rahman, A.R.M.M., Jalaluddin, I., Kasim, Z.M., \& Darmi, R. (2021). Aliya madrasah students' motivation for learning English in Bangladesh. Journal of Language and Linguistic Studies, 17(1), 70-84. Doi: 10.52462/jlls.5

Submission Date: 05/01/2021

Acceptance Date: 14/03/2021

\begin{abstract}
The purpose of the study was to investigate the factors and level of motivation for learning English among Aliya madrasah students in Bangladesh. The study also explored to find out the differences in students' motivation for learning English as L2 based on the gender of the students, parents' education level, and monthly family income of their parents. The data for this study was collected via a questionnaire survey among 300 participants selected through a simple random method from six Aliya madrasahs. The Adapted Attitude Motivation Test Battery (AMTB) questionnaire of Gardner $(1985,2004)$ was employed in this study. The data for this study was analysed quantitatively such as descriptive statistics, independent sample T-test, and one-way ANOVA using (SPSS) version 25 as a statistical tool. The results showed that most of the students were instrumentally motivated for learning English than integrative motivation and their motivation level was high. The analysis also showed that there was a statistically significant difference in their motivation for learning English based on their parents' monthly family income, and their parents' education level. However, the result revealed no significant difference in their motivation for learning English with regard to gender. On the basis of the results, the implications were discussed concerning students' motivation for learning English.
\end{abstract}

Keywords: Motivation; instrumental; integrative; Aliya madrasah; Bangladesh

\section{Introduction}

English is considered as a lingua franca and a global language or imperative language (Ashrafuzzaman, Ahmed, \& Begum, 2021), as Crystal (2003) states that the English language is widely used in a large number of areas such as commerce, science, education, medicine, aviation, tourism, business, and international communication all over the world. Over 350 million people consider English as their first language and approximately above 430 million people claim it their second language (Wil, n.d.). In many countries, people consider it as a foreign language and teaches it as a compulsory subject from the primary education to the higher secondary level or even teaches it as a foundation course at the tertiary level of education. In Bangladesh, it is considered either as a second language (Golam \& Kusakabe, 2018) or a foreign language (Akteruzzaman \& Islam, 2017) since

\footnotetext{
${ }^{1}$ Corresponding author.

E-mail address: rashedrahman52@yahoo.com
} 
nothing is clearly mentioned regarding the status of English in the constitution of Bangladesh (Zaaira, 2020). But it is a frequently used language after Bangla, the national language, in the government and non-government offices, education, and jobs. Thus its value or importance in Bangladesh is interminable.

Realizing the importance of English in Bangladesh, this language is taught as a compulsory subject in all the streams of education including general education, vocational education, and madrasah education. In Aliya madrasah, one of the sub-streams in the madrasah stream, English is taught right from the primary level. Aliya madrasah students follow the English curriculum, syllabus, and materials same as the students of general and vocational streams. Moreover, their duration of learning English is equal to the students of the general and vocational streams. Despite this, Aliya madrasah students are criticized by a section of the society in media and social media for their deficiency of proficiency in English. It is claimed that madrasah students are less proficient in English compared to the students of other streams. For example, Prof. Mesbah Kamal claims, "Madrasah students who are admitted to Dhaka University possess proficiency in English equivalent to the proficiency of class IV level students of general education stream" (Haque, 2018). Because of such a hypothetical claim, the madrasah students are often deprived of many opportunities including higher education and jobs. As Mamun and Shaon (2018) say that though the Aliya madrasah education is equivalent to the general education, the Aliya madrasah students face difficulties and discrimination in getting mainstream jobs in Bangladesh. Similarly, respecting the higher education the madrasah students were denied undergraduate admission in some specific subjects such as Bangla, English, and Economics in spite of securing good positions like the 1st, 2nd, 5th, 6th, 7th, and 9th (Protibedok, 2014). Even the Aliya madrasah students are found to obtain good results in the public examinations like Dakhil and Alim, as Report (2018) states, while the HSC pass rate for the technical board is 75.5 percent, the Alim (equivalent to Higher Secondary Certificate) pass rate is 78.67 percent. While the madrasah students are found to perform so well in the public examinations as well as in the university admission tests, it is a matter of concern why their proficiency in English is suspected and why they are denied of opportunities for this suspected deficiency of proficiency. It is often said that since the madrasah education gives emphasis on learning of the Arabic language and Islamic studies, the students may be found reluctant in learning English. Thus, the suspected deficiency of proficiency is often attributed to a number of factors including motivation for learning English since motivation is found to be associated with proficiency. Hence, this paper explores the Aliya madrasah students' motivation for learning English and the constraints that influence their motivation.

\subsection{Literature review}

Motivation is an important phenomenon associated with learning an L2. Generally, it is a complex psychological process, an internal drive that induces an individual to perform an activity, as Dornyei (2001, p. 7) says, "Motivation explains why people decide to do something, how hard they are going to pursue it, and how long they are willing to sustain the activity." Similarly, Huitt $(2011, p .1)$ perceives motivation as a desire, an internal state that activates behaviour, intensify it, and gives it a goal-oriented direction. Ryan and Deci (2000, p. 54) also opine that "to be motivated means to be moved to do something". All these notions suggest that an increase in motivation enhances activities, but lack of motivation decreases activities. Thus, with regard to learning an L2, motivation is found to play a significant and crucial role, as Ulfa and Bania (2019) opine, "Motivation is a key in learning other languages." Rubrecht and Ishikawa (2012) also say that motivation for learning an L2 demonstrates how hard a person works to learn the language and how happy he/she is with the tasks. While the abundance of motivation enhances the success of learning a new language (Gardner, 2001), 
lack of motivation is the main barrier in learning the language (Azar \& Tanggaraju, 2020). This clearly indicates that motivation constraints L2 learning.

Motivation is mainly found to be either integrative or instrumental or both. Integrative motivation refers to the learners' desire to assimilate in the target culture as well as the social life of the target language community (Brown, 1994; Rozmatovna, 2020), as Saville (2006) opines that socialization or participation in the target language community encourages learners to learn a second language. In this connection, Masgoret and Gardner (2003) opine that learners who are motivated integratively have their tendency to accept other language group as well as showing positive attitudes in the learning process. Hudson (2017) finds that integrative motivation provides valuable insights about learning English among the overseas learners at New College Lanarkshire. This integrative motivation, according to Deci and Ryan (1985), is intrinsic since the learners develop content understanding, tend to enjoy the learning experience, and be more tenacious in their aims. The instrumental motivation, however, refers to the desire for learning a language for some particular beneficial purposes or external rewards such as passing examinations, securing admission into better universities/colleges, or getting a good job, as Lambert (1974, p. 98) says that people learn an L2 considering "the practical value and advantages of learning a new language". Thus, Ryan and Deci (2000) claim that this type of motivation is extrinsic motivation that centres on the rewards of activity rather than pleasure.

While some studies identify the effects of instrumental motivation in L2 learning, other studies find out the effects of integrative motivation, and some other studies still observe the effects of both the instrumental and integrative motivations. For example, while Hong and Ganapathy (2017) observed that ESL Malaysian students' proficiency in English was influenced more by their instrumental motivation compared to their integrative motivation, Engin (2009) found in Turkey that integrative motivation is more effective than the instrumental motivation in learning English as L2. Yu and Downing (2012) however found in China that non-Asian students were highly integratively motivated, but Asian students were highly instrumentally motivated to learn English. While these studies identify the influence of either motivation, Wallace, and Leong (2020) found that EFL Chinese students demonstrate high instrumental as well as integrative motivation for learning English. Similarly, Zhang, Dai and Wang (2020) also found that proficiency in English of the English major university students in China is constrained by their integrative and instrumental motivations. Above all, the findings of these studies suggest that whatever its type or nature, motivation is found to have a crucial role in learning English as an L2.

The effects and intensity of motivation in learning an L2 are, however, found to be constrained by different factors such as gender, ethnicity, age, parental influence, and income. As far as gender is concerned, Daif-Allah and Aljuma (2020) found that females have more motivation to learn English than the males while Daud, Wong, Ghani, and Ramli (2021) found that males received more Arabic proficiency than females though some studies concluded with no significant difference in motivation for learning L2 in terms of gender (Özer, 2019). Respecting the parents' education level, Iwaniec (2018) observed differences in motivation for learning an L2. Butler (2015) also found the variation of motivation for learning an L2 in terms of parents' education level. Besides, Butler (2015) observed that parents' income also affects motivation for learning an L2.

A review of related literature suggests that effects of motivation on L2 learning and motivational factors are found to be studied across different contexts in the world, but these phenomena have not been explored yet with reference to the madrasah students in Bangladesh. Since madrasah students are criticized for their hypothesized deficiency of proficiency in English and deprived of many opportunities including higher education and jobs for this, it is worthy to explore the nature and level of their motivation for learning English along with the factors that constraint their motivation. 


\subsection{Research questions}

The objectives of the current study are to find out the obstacles to learn English centering on the motivational issues among madrasah students in Bangladesh. For this reason, the following questions are formulated:

(1) What are the factors that motivate Aliya madrasah students in Bangladesh to learn the English language?

(2) What are the levels of motivation for learning English of Aliya madrasah students in Bangladesh?

(3) To what extent do Aliya madrasah students' motivation for learning English differ based on gender, monthly family income of their parents, and education status of their parents in Bangladesh?

\section{Method}

\subsection{Research Design}

The researchers used a quantitative research design in this study. Quantitative research design focuses on the collection and analysis of numerical data to provide an overview of groups of people or a particular phenomenon (Mertler, 2018). The study was designed as a model of the survey while it provided a numerical or quantitative account of tendencies, views, or motivation on a sample selected from the population. This research design implied collecting data from a sample selected at a single point in time to represent the total population.

\subsection{Participants}

The research was conducted in Rangpur district, Bangladesh. The population of the study consisted of Alim level students of the Aliya madrasah in Bangladesh. A sum of 300 students was selected as a sample from six Aliya madrasahs through a simple random sampling method. An account of the sample of this study is shown in Table 1. The sample included both males (51.3\%) and females (48.7\%). Table 1 shows that the education level of the parents of the participants ranges from below SSS (Secondary School Certificate)/Dakhil to postgraduate/Kamil and the monthly family income ranges from below Tk.10000 to Tk. 50000/above.

Table 1. Demographic profile of the participants

\begin{tabular}{llll}
\hline Description & Group & Frequency (N=300) & Percentage (\%) \\
\hline \multirow{2}{*}{ Gender of the participants } & Male & 154 & 51.3 \\
& Female & 146 & 48.7 \\
\hline \multirow{3}{*}{ Parents' education level } & Postgraduate /Kamil & 22 & 7.3 \\
& Undergraduate /Fazil & 54 & 18.0 \\
& HSC/Alim & 113 & 37.7 \\
& SSC/Dakhil & 53 & 17.7 \\
& Below SSC/Dakhil & 58 & 19.3 \\
\hline \multirow{3}{*}{ Monthly family income } & BDT 50000/above (high) & 43 & 14.3 \\
& BDT 20000-49000 (middle & 75 & 25.0 \\
& high) & & 39.0
\end{tabular}


low)

BDT Below 10000 (low) 65

\subsection{Instrument}

The instrument of this research was a questionnaire adapted from Gardner's $(1985,2004)$ Attitude Motivation Test Battery (AMTB) in line with the research objectives. The questionnaire had two parts: the first part comprised the background information of the participants including their gender, parents' status of education, and monthly family income, and the second part consisted of 10 items with two sub dimensions (instrumental and integrative) of motivation. To assess the content validity, the instrument was sent to experts and their feedback and comments were incorporated into this study. In questionnaire, the respondents gave their opinion based on 5-point Likert scale that is, $1=$ strongly disagree, $2=$ disagree, $3=$ neutral, $4=$ agree, and $5=$ strongly agree. The researchers translated the English version questionnaire to Bangla by a professional translator. The translation was performed because the participants were not adequately fluent in English. Besides, it was translated into Bangla to avoid the probability of confusion of the English questionnaire. The Cronbach Alpha value for instrumental motivation was .81, and integrative motivation .71.

\subsection{Data collection procedures}

Prior to collect data for this study, it was confirmed by the participants via filling out a consent form that they were participating in the study voluntarily and they had no objection to participate in this research. It was assured to the participants that their information will remain firmly confidential and the data will be used for the research purposes only. A prior permission was obtained from the authority of the concerned madrasah also. The questionnaires were administered in the classrooms of the selected madrasahs and so, the participants were informed to be present in the classroom to ensure their participation. One of the researchers were present in the class during the data collection procedures to explain the ambiguity if the participants encountered. The participants were given adequate time to complete the questionnaires. Finally, the researcher collected the completed questionnaires from the participants with giving thanks.

\subsection{Data analysis}

To analyse, the data given by the respondents were computed and analysed by using the statistical tool SPSS. To find out participants' motivational factors for learning English and their level of motivation, descriptive statistics were applied. The mean scores of the data were calculated and categorized as: very high $=4.5-5.0$, high $=3.5-4.49$, average $=2.5-3.49$, low $=1.5-2.49$, and very low $=1.0-1.49$, following Degang (2010) and Kitjaroonchai (2012), to determine the types and levels of participants' motivations for learning English. Before analysing, the normal distribution of the collected data was checked and found that the data were normally distributed. To identify the differences in participants' motivations for learning English in terms of their gender, parents' education level, and monthly family income an Independent sample $t$-test and one way ANOVA analysis was conducted.

\section{Results}

This part shows the findings of item analysis that related to participants' motivation for learning English. 
Table 2 shows the overall mean score of motivation $(M=4.22)$ which indicates that the students are highly motivated for learning the English language. While their instrumental and integrative motivations individually as well as their averages are found to be high, their instrumental motivations are higher compared to their integrative motivation.

Table 2. Overall mean and average mean for instrumental and integrative motivation

\begin{tabular}{lcc}
\hline Motivation category & Mean & Level of motivation \\
\hline Instrumental motivation & 4.30 & High \\
Integrative motivation & 4.14 & High \\
Overall motivation & 4.22 & High \\
\hline
\end{tabular}

Frequency counting of the Items 1 to 5 presented in Table 3 shows participants' instrumental motivation for learning the English language. The table shows that $87.3 \%$ ( $\mathrm{A}=56.3 \%$ \& $\mathrm{SA}=31.0 \%)$ of the participants opine that they have to learn English because they want to pass English courses (Item 1). Though a very few of them are found to remain neutral in their opinion respecting this issue, a highly insignificant percentage of them are found to disagree with the view. With regard to Item 2, most of the participants (94.6\%, i.e., $\mathrm{A}=57.3 \%$ \& SA=37.3\%) feel that they want to learn English because they would like to study in a university where courses are taught in English. None of them are found to disagree with this opinion, though a very negligible percentage of them remained neutral in their opinion. It is also seen in the table relating to the Item 3 that $83 \%$ of the participants $(A=48.0 \%$ \& $\mathrm{SA}=35.0 \%$ ) want to learn English as it will help them to go abroad for higher studies. Though some of them remained neutral on this issue, no one of them are, however, reported to disagree with the view. In relation to the Item 4 , most of the participants, that is, $94 \%(\mathrm{~A}=45.7 \% \& \mathrm{SA}=48.3 \%)$ hold the view that they want to learn English as it is useful to get a good job. While a very few percentages of the participants disagree with this view, an almost unmentionable percentage of them are found to remain neutral. Similar to the Item 4, most of the participants, that is, $94.6 \%(\mathrm{~A}=42.3 \%$ \& SA=52.3\%) believe with reference to the Item 5 that they want to learn English because with proficiency in English they can work globally. Although a very little percentage of the participants show a neutral stance regarding the issue, almost negligible percentages of them are found to disagree with this view.

In short, it is apparent from the table that the participants hold highly positive instrumental motivation for learning the English language. Though the mean score for each item is found to vary slightly from one another, the average of the mean scores is 4.30 , which could be an indication of their high instrumental motivation for learning the language according to the mean range categories mentioned in the section 2.4 above.

Table 3. Instrumental motivation of the participants for learning English

\begin{tabular}{lccccccc}
\hline Item & SD & $\mathrm{D}$ & $\mathrm{N}$ & $\mathrm{A}$ & $\mathrm{SA}$ & $\mathrm{M}$ & $\begin{array}{c}\text { Level of } \\
\text { motivation }\end{array}$ \\
\hline Item 1 & - & 2.0 & 10.7 & 56.3 & 31.0 & 4.16 & High \\
Item 2 & - & - & 5.3 & 57.3 & 37.3 & 4.32 & High \\
Item 3 & - & - & 17.0 & 48.0 & 35.0 & 4.18 & High \\
Item 4 & - & 1.0 & 5.0 & 45.7 & 48.3 & 4.41 & High \\
Item 5 & 0.3 & - & 5.0 & 42.3 & 52.3 & 4.46 & High
\end{tabular}

Note: $\mathrm{SD}=$ Strongly Disagree, $\mathrm{D}=$ Disagree, $\mathrm{N}=$ Neutral, $\mathrm{A}=$ Agree, $\mathrm{SA}=$ Strongly Agree, M=Mean, Item 1:I have to learn the English language because I want to pass English courses, Item 2: I want to learn the English language because I would like to study in a university where courses are taught in English language, Item 3: I want to learn the 
English language because it will help me to go abroad for higher studies, Item 4: I want to learn the English language because it is useful to get a good job, Item 5: I want to learn the English language because with proficiency in English I can work globally.

Frequency counting of the Items 6 to 10 presented in Table 4 demonstrate participants' integrative motivation for learning English. It can be seen from this table that the majority of the participants (82\%, i.e., $\mathrm{A}=47.7 \% \& \mathrm{SA}=34.3 \%)$ are of the view with reference to the Item 6 that they want to learn English because they want to converse with English speakers. While a few of them are found to hold a neutral stance, a highly negligible percentage are found to disagree with this view. With regard to the Item 7, while a substantial number of the participants (79.3\%, i.e., $\mathrm{A}=58.3 \% \& \mathrm{SA}=21.0 \%)$ want to learn English to communicate with foreigners, some of them are found to remain neutral but almost a negligible percentage of them express their disagreement with this view. Whereas a sizable number of the participants (89.3\%: $\mathrm{A}=50.3 \%$ \& SA=39.0\%) want to learn English to know the culture of the English-speaking countries (Item 8), a very little percentage of them hold a neutral stance and a nearly negligible percentages of them are reported to disagree with the perception. Likewise, with regard to the Item 9, while $85 \%(\mathrm{~A}=47.0 \%$ \& $\mathrm{SA}=38.0 \%)$ of the participants feel to learn English with an aim to live in an English speaking country, a very low percentage of them are neutral about this view and almost an unmentionable percentage of them are found to disagree with the idea. Concerning the Item 10 , it can also be seen from the table that $78.6 \%(\mathrm{~A}=43.3 \% \& \mathrm{SA}=35.3 \%)$ of the participants like to learn English to use social media (e.g., Facebook, Whatsapp, Twitter) in English and watch English TV programs. Though some of them are found to remain neutral regarding this view, a highly insignificant percentage of them are found to disagree with this idea.

In brief, it appears that the participants demonstrate highly positive integrative motivation for learning English. Despite slight variation in the mean score of individual items, the average mean score is 4.14 , which suggests, according to the motivation range categories mentioned in the Section 2.4 above, the high integrative motivation of the participants for learning the language.

Table 4. Integrative motivation of the participants for learning English

\begin{tabular}{cccccccc}
\hline Item & SD & D & N & A & SA & M & $\begin{array}{c}\text { Level of } \\
\text { motivation }\end{array}$ \\
\hline Item 6 & - & 1.3 & 16.7 & 47.7 & 34.3 & 4.15 & High \\
Item 7 & 0.7 & 2.0 & 18.0 & 58.3 & 21.0 & 3.97 & High \\
Item 8 & - & 0.3 & 10.3 & 50.3 & 39.0 & 4.28 & High \\
Item 9 & 0.3 & - & 14.7 & 47.0 & 38.0 & 4.22 & High \\
Item 10 & - & 3.7 & 11.7 & 43.3 & 35.3 & 4.10 & High \\
\hline $\begin{array}{l}\text { Note: SD=Strongly Disagree, D= Disagree, N=Neutral, A=Agree, SA=Strongly Agree, M=Mean, Item 6: I want to learn the English language because I want to } \\
\text { verse with English speakers, Item 7: I learn the English language because I want to communicate with foreigners, Item 8: I learn the English language because I want to }\end{array}$ \\
ow the culture of English-speaking countries, Item 9: I learn the English language because I would like to live in an English speaking country, Item 10: I like to learn the
\end{tabular}

Table 5 and 5.1 present independent samples $t$-test results which indicate whether students' motivation differ based on their gender. Table 5 shows that male students $(\mathrm{M}=4.25, \mathrm{SD}=.37)$ scored slightly higher than the females $(\mathrm{M}=4.19, \mathrm{SD}=.35)$ but Table 5.1 suggests, based on the findings of independent samples $t$-test, $t(298)=1.36, p=.175,95 \%$ CI [-0.02, 0.14], no significant difference of motivation between male and female students at alpha level of .05 . 
Table 5. Group Statistics

\begin{tabular}{llcccc}
\hline \multirow{3}{*}{ Motivation } & Gender & $\mathrm{N}$ & Mean & Std. Deviation & Std. Error Mean \\
\cline { 2 - 6 } & Male & 154 & 4.2545 & .3785 & .0305 \\
& Female & 146 & 4.1973 & .3509 & .0290 \\
\hline
\end{tabular}

Table 5.1. Independent Samples Test

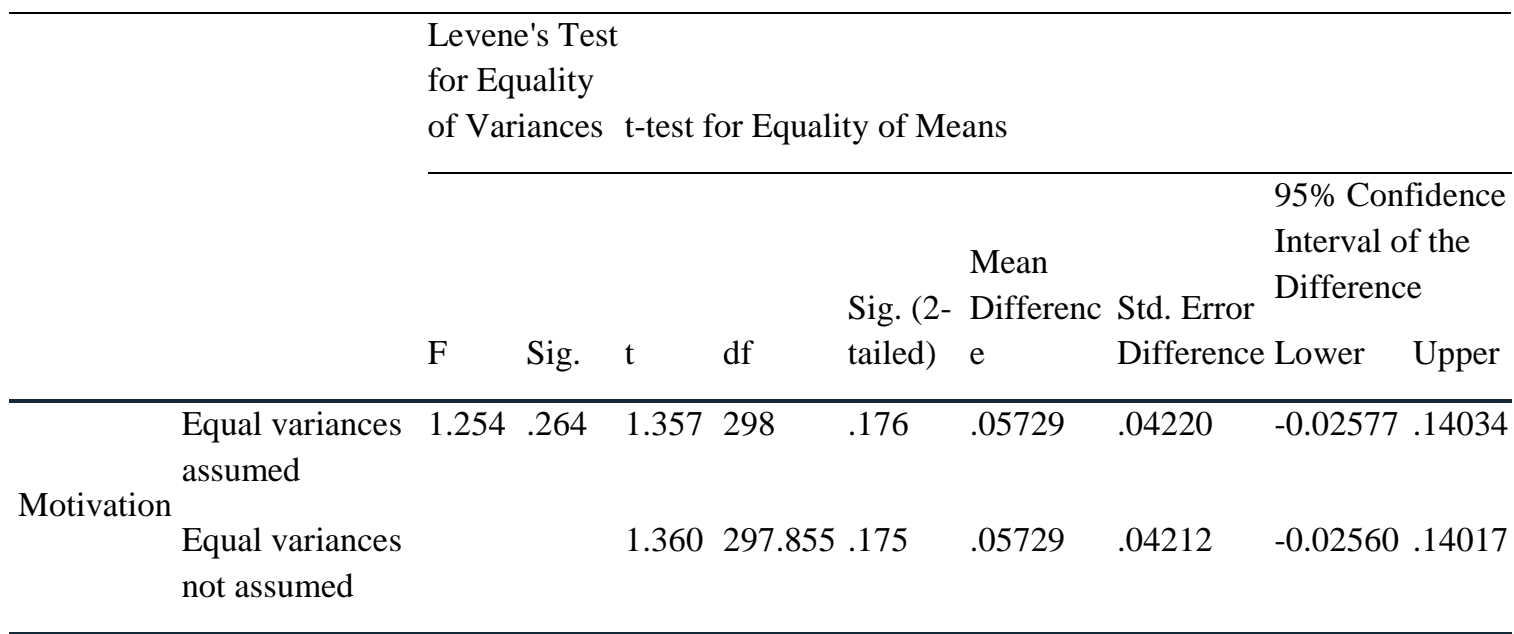

Table 6 and 6.1 represent the findings of the one-way ANOVA to decide whether students' motivation differs based on the monthly family income of their parents. Table 6 shows that there is a statistically significant difference in their motivation in relation to their parent's monthly family income $F(3,296)=6.59, p<.05$, since the significant value $(p=.000)$ is smaller than $\alpha$ at .05 level.

Table 6. ANOVA

\begin{tabular}{llllll}
\hline & Sum of Squares & df & Mean Square & F & Sig. \\
\hline Between Groups & 1.778 & 3 & .593 & 6.591 & $\mathbf{. 0 0 0}$ \\
Within Groups & 26.621 & 296 & .090 & & \\
Total & 28.400 & 299 & & &
\end{tabular}

Furthermore, Table 6.1 presents the Post Hoc analysis to determine group difference. The table demonstrates that there is a statistically significant difference in motivation for learning English between groups of BDT 500000/above and BDT 10000-19000 ( $p=.000)$, BDT 500000/above and Below BDT 10000 ( $p=.000)$, BDT 20000-49000 and BDT 10000-19000 ( $p=.000)$, BDT 2000049000 and Below BDT 10000 ( $p=.000)$, since the $\mathrm{p}$ value is less than Alpha level $(\mathrm{p}<.05)$. There is a meaningful difference between these groups which means that the participants belonging to the highincome parents demonstrate a high motivation for learning English than the participants belonging to the low-income parents. 
Table 6.1. Post Hoc (Multiple Comparisons)

\begin{tabular}{|c|c|c|c|c|c|c|}
\hline \multicolumn{7}{|l|}{ Tukey HSD } \\
\hline \multirow[b]{2}{*}{$\begin{array}{l}\text { (I) Monthly Family } \\
\text { Income }\end{array}$} & \multirow[b]{2}{*}{$\begin{array}{l}\text { (J) Monthly Family } \\
\text { Income }\end{array}$} & \multirow[b]{2}{*}{$\begin{array}{c}\text { Mean Difference } \\
\text { (I-J) }\end{array}$} & \multirow[b]{2}{*}{ Std. Error } & \multirow[b]{2}{*}{ Sig. } & \multicolumn{2}{|c|}{$\begin{array}{l}\text { 95\% Confidence } \\
\text { Interval }\end{array}$} \\
\hline & & & & & Lower Bound & $\begin{array}{l}\text { Upper } \\
\text { Bound }\end{array}$ \\
\hline \multirow{3}{*}{ 500000/above(BDT) } & $20000-49000$ & .02538 & .05736 & .971 & -.1228 & .1736 \\
\hline & $10000-19000$ & $.15046^{*}$ & .05348 & .027 & .0123 & .2886 \\
\hline & Below 10000 & $.20033^{*}$ & .05895 & .004 & .0480 & .3526 \\
\hline \multirow{3}{*}{ 20000-49000(BDT) } & 500000/above & -.02538 & .05736 & .971 & -.1736 & .1228 \\
\hline & $10000-19000$ & $.12508^{*}$ & .04436 & .026 & .0105 & .2397 \\
\hline & Below 10000 & $.17495^{*}$ & .05082 & .004 & .0436 & .3063 \\
\hline \multirow{3}{*}{ 10000-19000(BDT) } & 500000/above & $-.15046^{*}$ & .05348 & .027 & -.2886 & -.0123 \\
\hline & $20000-49000$ & $-.12508^{*}$ & .04436 & .026 & -.2397 & -.0105 \\
\hline & Below 10000 & .04987 & .04639 & .705 & -.0700 & .1697 \\
\hline \multirow{3}{*}{ Below 10000(BDT) } & 500000/above & $-.20033^{*}$ & .05895 & .004 & -.3526 & -.0480 \\
\hline & $20000-49000$ & $-.17495^{*}$ & .05082 & .004 & -.3063 & -.0436 \\
\hline & $10000-19000$ & -.04987 & .04639 & .705 & -.1697 & .0700 \\
\hline
\end{tabular}

Note: BDT= Bangladesh taka

Table 7 and 7.1 represent the findings of the one-way ANOVA which help to decide whether students' motivation differs based on education level of their parents. Table 6 shows that there is a statistically significant difference in their motivation with regard to their parent's education level $F(4,295)=4.23, \mathrm{p}<.05$, since the significant value $(\mathrm{p}=.002)$ is smaller than $\alpha$ at .05 level.

Table 7. ANOVA

\begin{tabular}{llllll}
\hline & Sum of Squares & df & Mean Square & F & Sig. \\
\cline { 2 - 6 } Between Groups & 1.541 & 4 & .385 & 4.230 & $\mathbf{. 0 0 2}$ \\
Within Groups & 26.859 & 295 & .091 & & \\
Total & 28.400 & 299 & & & \\
\hline
\end{tabular}

Moreover, the significance of group difference can be found from the Post Hoc analysis shown in Table 7.1. The table demonstrates a statistically significant difference in motivation for learning English between groups of Postgraduate/Kamil and Below SSC/Dakhil ( $\mathrm{p}=.006)$, Undergraduate/Fazil and HSC/Alim ( $\mathrm{p}=.025)$, Undergraduate/Fazil and SSC/Dakhil ( $\mathrm{p}=.000)$, Undergraduate/Fazil and Below SSC/Dakhil $(\mathrm{p}=.000)$, HSC/Alim and SSC/Dakhil $(\mathrm{p}=.004)$, HSC/Alim and Below SSC/Dakhil $(\mathrm{p}=.000)$ since the $\mathrm{p}$ value is less than Alpha level $(\mathrm{p}<.05)$. This means that the students with parents who have a higher education have a higher motivation for learning English than the students with parents who have low education. 
Table 7.1. Post Hoc (Multiple Comparisons)

Tukey HSD

\begin{tabular}{|c|c|c|c|c|c|c|}
\hline \multirow{3}{*}{$\begin{array}{c}\text { (I) Parents Education } \\
\text { Status }\end{array}$} & \multirow{3}{*}{$\begin{array}{c}\text { (J) Parents } \\
\text { Education Status }\end{array}$} & \multirow{3}{*}{$\begin{array}{c}\text { Mean } \\
\text { Difference (I-J) }\end{array}$} & \multirow[b]{3}{*}{ Std. Error } & \multirow[b]{3}{*}{ Sig. } & \multicolumn{2}{|c|}{$\begin{array}{l}95 \% \text { Confidence } \\
\text { Interval }\end{array}$} \\
\hline & & & & & & Upper \\
\hline & & & & & Lower Bound & Bound \\
\hline \multirow{4}{*}{ Postgraduate/Kamil } & Undergraduate/Fazil & -.01760 & .07632 & .999 & -.2271 & .1919 \\
\hline & HSC/Alim & .01955 & .07032 & .999 & -.1734 & .2125 \\
\hline & SSC/Dakhil & .12343 & .07653 & .490 & -.0866 & .3335 \\
\hline & Below SSC/Dakhil & .17282 & .07555 & .152 & -.0346 & .3802 \\
\hline \multirow{4}{*}{ Undergraduate/Fazil } & Postgraduate/Kamil & .01760 & .07632 & .999 & -.1919 & .2271 \\
\hline & HSC/Alim & .03715 & .04992 & .946 & -.0999 & .1742 \\
\hline & SSC/Dakhil & $.14103^{*}$ & .05834 & .114 & -.0191 & .3012 \\
\hline & Below SSC/Dakhil & $.19042^{*}$ & .05706 & .008 & .0338 & .3470 \\
\hline \multirow{4}{*}{ HSC/Alim } & Postgraduate/Kamil & -.01955 & .07032 & .999 & -.2125 & .1734 \\
\hline & Undergraduate/Fazil & -.03715 & .04992 & .946 & -.1742 & .0999 \\
\hline & SSC/Dakhil & .10388 & .05024 & .237 & -.0340 & .2418 \\
\hline & Below SSC/Dakhil & $.15327^{*}$ & .04874 & .016 & .0195 & .2870 \\
\hline \multirow{4}{*}{ SSC/Dakhil } & Postgraduate/Kamil & -.12343 & .07653 & .490 & -.3335 & .0866 \\
\hline & Undergraduate/Fazil & -.14103 & .05834 & .114 & -.3012 & .0191 \\
\hline & HSC/Alim & -.10388 & .05024 & .237 & -.2418 & .0340 \\
\hline & Below SSC/Dakhil & .04939 & .05734 & .911 & -.1080 & .2068 \\
\hline \multirow{4}{*}{ Below SSC/Dakhil } & Postgraduate/Kamil & -.17282 & .07555 & .152 & -.3802 & .0346 \\
\hline & Undergraduate/Fazil & $-.19042^{*}$ & .05706 & .008 & -.3470 & -.0338 \\
\hline & HSC/Alim & $-.15327^{*}$ & .04874 & .016 & -.2870 & -.0195 \\
\hline & SSC/Dakhil & -.04939 & .05734 & .911 & -.2068 & .1080 \\
\hline
\end{tabular}

\section{Discussion}

The principal focus of the current study was to identify factors that motivate Aliya madrasah students for learning English. From the analysis of the collected data, the researchers have obtained a clear picture of the motivational factors that promote the learning process of the madrasah students the most. Concerning the first research question, this study shows that the students hold high instrumental and integrative motivations for learning English. Their high instrumental motivation could be attributed to the fact that they learn English for their pragmatic purposes including achieving academic success and getting a good job. They seem to perceive the English language as an instrument to gain success and benefits. This finding is similar to other studies such as Aliakbari and Monfared, 2014; AlTa'ani, 2018; Hong and Ganapathy, 2017; and Hussain and Masum, 2016. These studies found that the students are instrumentally motivated for learning an L2 compared to other types of motivation. 
Students who are motivated instrumentally for learning English are found to learn English for practical purposes such as to get a suitable job, to join a university, or to achieve academic success. Their high integrative motivation for learning English however could be explained with reference to their desire for participation in global social media communication and global migration. As they are reported to use English for social media communication, English is gradually turning into their common language of everyday communication. It is said that those who possess high integrative motivation for learning English may use English naturally with their friends or family members meaning that English is a common language in their linguistic ecology. This finding aligns with the findings of some other studies such as Kadir et al. (2020) and Strong (1984).

Respecting the second research question, the findings demonstrated that though the respondents had overall high instrumental and integrative motivation for learning English, their instrumental motivation was stronger compared to their integrative motivation. This finding is also in line with some other studies such as Al-Ta'ani (2018); Daif-Allah and Aljuma (2020); Kadir et al. (2020); and Wallace and Leong (2020). These studies also confirmed that participants' instrumental motivation level was higher compared to their integrative motivation level. However, the participants' level of integrative motivation was not low.

Related to the third research question, the study revealed that the madrasah students' motivation did not significantly differ with regard to their gender. This finding is similar to Özer (2019). Özer (2019) found no significant motivational difference based on gender. However, Daif-Allah and Aljuma (2020) obtained a different result that contradicts with the findings of the current study. They uncovered that female student were highly motivated to learn English than the males.

Parents' monthly income was, however, found to contribute significantly to learners' motivation. This result is also similar to the study conducted by Butler (2015). Her study revealed that the higher SES (includes such as income) background students show higher motivation compared to the lower SES students. So, it appears that income has an influence in determining students' motivation for learning English.

Parents' education level was also identified as a significant factor for learners' motivation for learning English. The study showed that the children whose parents had higher education were more motivated to learn English compared to the children whose parents had low education background. The result is also in line with the study such as Butler (2015) and Iwaniec (2018). Iwaniec (2018) found that those students whose parents have higher education are more motivated to learn English compared to the students whose parents have lower education levels. Hence, it is apparent that parents' education level can constraint students' motivation for learning an L2.

\section{Conclusions}

This study added relevant insights into the existing body of knowledge about the types and levels of motivation for learning an L2 such as English. It shows that most of the participants hold high instrumental and integrative motivation for learning English through their instrumental motivation was stronger than their integrative motivation. The study also revealed that though there was no significant difference in their motivation in terms of their gender, their motivations were found to significantly vary with reference to their parents' education level and their parents' monthly income. These findings have important implications for both the teachers and students. Students should focus on enhancing their motivations for learning the language with positive attitudes. They should continue learning and using English with joy both inside and outside the class and they should not consider it an additional load or burden. The English teachers also must try to enhance students' motivation for achieving desired goals in learning English. They should make English class enjoyable by adapting a variety of 
teaching materials, methodologies, and techniques to enhance students' motivation for learning English.

This study has its limitations. The study focused on exploring the motivation of the Alim level Aliya madrasah students only and hence, the results of this study may not be applicable for other streams of education in Bangladesh. Besides, the use of combined methods such as observation, interview, and survey rather than a single method provides better, reliable and valid results which were not used in this research. So, the phenomena can be further investigated by using other methods of data collection comprising different participants of other streams of education.

\section{References}

Akteruzzaman, M., \& Islam, R. (2017). English, Education, and Globalisation: A Bangladesh Perspective. IAFOR Journal of Education, 5(1), 185-206.

Aliakbari, M. \& Monfared, M. (2014). Iranian students' beliefs and motivations towards English. Procedia - Social and Behavioral Sciences, 98, 200 - 206.

Al-Ta'ani, M. H. (2018). Integrative and instrumental motivations for learning English as a university requirement among undergraduate students at Al-Jazeera University/Dubai. International Journal of Learning and Development, 8(4), 89- 105.

Ashrafuzzaman, M., Ahmed, I., \& Begum, M. (2021). Learning English language through literature: Insights from a survey at university level in Bangladesh. Journal of Language and Linguistic Studies, 17(Special Issue 2), 1190-1209.

Azar, A. S., \& Tanggaraju, D. (2020). Motivation in second language acquisition among learners in Malaysia. Studies in English Language and Education, 7(2), 323-333.

Brown, H. D. (1994). Principles of language learning and teaching $\left(3^{\text {rd }}\right.$ ed.). New Jersey: Prentice Hall.

Butler, Y. G. (2015). Parental factors in children's motivation for learning English: A case in China. Research papers in Education, 30(2), 164-191.

Crystal, D. (2003). English as a global language ( $\left.2^{\text {nd }} e d\right)$. New York: Cambridge University Press.

Daif-Allah, A. S., \& Aljumah, F. H. (2020). Differences in Motivation to Learning English among Saudi University Students. English Language Teaching, 13(2), 63-74.

Daud, W.A.A.W., Wong, K.T., Ghani, M. T.A., \& Ramli, S.B. (2021). Gender differences in Learning Arabic Language Proficiency via M-learning among Malaysia University Students. Journal of Language and Linguistic Studies, 17(Special Issue 2), 1069-1082.

Deci, E. L., \& Ryan, R. M. (1985). Intrinsic motivation and self-determination in human behaviour. New York: Plenum.

Degang, M. (2010). Motivation toward English language learning of the second year undergraduate Thai students majoring in Business English at an English-medium university. Unpublished MA thesis, University of Srinakharinwirot, Thailand.

Dornyei, Z. (2001). Teaching and Researching Motivation. Harlow, England: Longman.

Engin, A. O. (2009). Second language learning success and motivation. Social Behavior and Personality: an international journal, 37(8), 1035-1041. 
Gardner, R. C. (1985). Social psychology and second language learning: The role of attitudes and motivation. Arnold.

Gardner, R. C. (2001). Language learning motivation: The student, the teacher, and the researcher. Texas Papers in Foreign Language Education, 6(1), 1-18.

Gardner, R. C. (2004). Attitude/motivation test battery: International AMTB research project. Canada: The University of Western Ontario.

Golam, A. M., \& Kusakabe, T. (2018). A qualitative study of English teaching in Bangladesh: A case study of Madrasa education. US-China Education Review, 8(3), 106-122.

Haque, M. S. (2018, February 14). মাদরাসাশিক্ষাওএকজনঅধ্যাপকেরবক্তব্য (madrasah sikka o ekjonoddapokerboktobbo). The daily Campus. Retrieved May 09, 2020 from http://www.dainikcampus.com/মাদরাসা-শিক্ষা-ও-একজন-অধ্/

Hong, Y. C., \& Ganapathy, M. (2017). To Investigate ESL Students' Instrumental and Integrative Motivation towards English Language Learning in a Chinese School in Penang: Case Study. English Language Teaching, 10(9), 17-35.

Hudson, J. (2017). Integrative motivation and second language learning: the role of integrative motivation among ESOL learners at a Scottish college. Language Issues: The ESOL Journal, 28(1), $23-35$.

Huitt, W. (2011). Motivation to learn: An overview. Educational psychology interactive.

Hussain, Z., \& Masum, M. J., (2016). Motivation of Bangladeshi higher secondary students in learning English language. Language in India, 16(2), 177-189.

Iwaniec, J. (2018). The effects of parental education level and school location on language learning motivation. The Language Learning Journal, 48(4), 427-441.

Kadir, Z. B. A., Abdullah, R. A. B., Palpanadan, S. T., Abidin, S. S. B. Z., Muhammad, S. S., \& Mohamed, A. A. (2020). Investigating Students' Attitude and Motivation in Learning English as a Second Language among Four Higher Institutions in Malaysia. PAROLE: Journal of Linguistics and Education, 10(1), 72-79.

Kitjaroonchai, N. (2012). Motivation toward English language learning of students in secondary and high schools in education service area office 4, Saraburi Province, Thailand. International Journal of Language and Linguistics, 1(1), 22-33.

Lambert, W. E. (1974). Culture and language as factors in learning and education. In F. E. Aboud \& R. D. Meade (Eds.), Cultural factors in learning and education. Proceedings of the Fifth Western Washington Symposium on Learning (pp. 91-122). Bellingham: Western Washington State College.

Mamun, S., \& Shaon, A. I. (2018, January 17). What are the career prospects for a madrasa student? Retrieved June 17, 2020 fromhttps://sabrangindia.in/article/what-are-career-prospects-madrasastudent

Masgoret, A., \& Gardner, R. C. (2003). Attitudes, motivation, and second language learning: A metaanalysis of studies conducted by Gardner and associates. Language Learning, 53(1), 123-163.

Mertler, C. A. (2018). Introduction to educational research. Sage publications. 
Protibedok, M. L. (2014, October 02). ঢাবিতেভর্তিঃসেরাআটশিক্ষার্থীপাচ্ছেননাপছন্দেরবিষয় (dhavitevorti: sera at shikkartipassennaposonderbisoy). Campus Live. Retrieved May 09, 2020, from https://campuslive24.com/old-site/68459/ঢাবিতে-ভর্তি-সেরা-আট- শিক্ষার্থী-পাচ্ছেন -না-পচ্দেন্দে-বিষয়

Özer, S. (2019). An Investigation of Attitude, Motivation and Anxiety Levels of Students Studying at a Faculty of Tourism towards Vocational English Course. Journal of Language and Linguistic Studies, 15(2), 560-577.

Report, S.O. (2018, July 19). HSC results: Pass rate, GPA 5 achievers drop. The Daily Star. Retrieved June 15, 2020 from https://www.thedailystar.net/country/hsc-exam-result-2018-education-ministerhands-over-to-pm-sheikh-hasina-1607797

Rozmatovna, A. O. (2020). The influence of integrative motivation and instrumental motivation on learning English as a Foreign Language. Journal of Critical Reviews, 7(12), 942-945.

Rubrecht, B. G., \& Ishikawa, K. (2012). Language learning motivation: Applying the L2 Motivational Self System. International Journal of Language Studies, 6(4), 71-96.

Ryan, R. M., \& Deci, E. L. (2000). Self-determination theory and the facilitation of intrinsic motivation, social development, and well-being. American Psychologist, 55(1), 68-78.

Saville-Troike, M. (2006). Introducing second language acquisition. New York: Cambridge University Press.

Strong, M. (1984). Integrative motivation: Cause or result of successful second language acquisition? Language Learning, 34(3), 1-13.

Ulfa, M., \& Bania, A. S. (2019). EFL student's motivation in learning English in Langsa, Aceh. Studies in English Language and Education, 6(1), 163-170.

Wallace, M. P., \& Leong, E. I. L. (2020). Exploring Language Learning Motivation among Primary EFL Learners. Journal of Language Teaching and Research, 11(2), 221-230.

Wil. (n.d.). How English became the global language. EF English Live. Retrieved November 5, 2020fromhttps://englishlive.ef.com/blog/english-in-the-real-world/english-became-globallanguage/

Yu, B., \& Downing, K. (2012). Determinants of international students' adaptation: Examining effects of integrative motivation, instrumental motivation and second language proficiency. Educational studies, 38(4), 457-471.

Zaaira. (2020, January 18). Condition of English in Bangladesh: second language or foreign language. Retrieved November 7, 2020 from https://zaaira.com/18/01/2020/trending/condition-of-english-inbangladesh-second-language-or-foreign-language/

Zhang, H., Dai, Y., \& Wang, Y. (2020). Motivation and Second Foreign Language Proficiency: The Mediating Role of Foreign Language Enjoyment. Sustainability, 12(4), 1302.

\section{AUTHORS BIODATA}

Abu Rashed Md. Mahbuber Rahman, is a Ph.D. candidate at the Department of English, Universiti Putra Malaysia. He received his B.A (Hons) \& M.A degree in English from Aligarh Muslim University, India. His research interests include English language Teaching, sociolinguistics, Linguistics, and SLA.

Ilyana Jalaluddin is a senior lecturer at UPM. She has researched and published books and articles related to TESL, the teaching of writing skills, ESL writing skills and self-efficacy development. Her current research focuses on the use of technology in teaching and learning of writing skills. 
Zalina Mohd Kasim, (Ph.D.) is an Associate Professor at the Department of English, Faculty of Modern Languages and Communication, Universiti Putra Malaysia. Her current research interests include cognitive stylistics, semiotics, applied linguistics, and discourse analysis.

Ramiza Darmi, Ph.D., is a Senior Lecturer in the Department of English, Faculty of Modern Languages and Communication, Universiti Putra Malaysia. She specialises in English language learning. Her research interests include second language learning, mobile language learning, and technology-enhanced language learning. Currently, her research focuses on reading for second language learners. 